$12-21-2018$

\title{
Religion and Progressive Politics in the United States
}

\author{
Ruth Braunstein \\ University of Connecticut \\ Todd N. Fuist \\ Illinois Wesleyan University \\ Rhys Williams \\ Loyola University Chicago, rwilliams7@luc.edu
}

Follow this and additional works at: https://ecommons.luc.edu/soc_facpubs

Part of the Sociology Commons

\section{Author Manuscript}

This is a pre-publication author manuscript of the final, published article.

\section{Recommended Citation}

Braunstein, Ruth; Fuist, Todd N.; and Williams, Rhys. Religion and Progressive Politics in the United States. Sociology Compass, 13, 2: , 2018. Retrieved from Loyola eCommons, Sociology: Faculty Publications and Other Works, http://dx.doi.org/10.1111/soc4.12656

This Article is brought to you for free and open access by the Faculty Publications and Other Works by Department at Loyola eCommons. It has been accepted for inclusion in Sociology: Faculty Publications and Other Works by an authorized administrator of Loyola eCommons. For more information, please contact ecommons@luc.edu. cc) (i) $\Theta$

This work is licensed under a Creative Commons Attribution-Noncommercial-No Derivative Works 3.0 License. (c) Wiley, 2018. 


\section{Religion and Progressive Politics in the United States}

\begin{tabular}{|r|l|}
\hline Journal: & Sociology Compass \\
\hline Manuscript ID & Draft \\
\hline Wiley - Manuscript type: & Article \\
\hline Keywords: & $\begin{array}{l}\text { Culture < Compass Sections, Political Sociology < Compass Sections, } \\
\text { Social Movements < Compass Sections, Social Movements and Social } \\
\text { Change < Subjects, Public Opinion < Communication and Media Studies }< \\
\text { Subjects, Politics < Subjects, Religion < Subjects, Political Sociology < } \\
\text { Government, Politics, and Law < Sociology < Subjects, Social Movements } \\
\text { and Social Change < Sociology < Subjects, Sociology of Religion < } \\
\text { Sociology < Subjects }\end{array}$ \\
\hline \multicolumn{2}{|l}{} \\
\hline
\end{tabular}

SCHOLARONE ${ }^{\mathrm{m}}$

Manuscripts 


\title{
Religion and Progressive Politics in the United States
}

\begin{abstract}
In recent years, scholars interested in the role of religion in American public life have largely focused on the Christian Right or the role of religion in civic life. Compared to these extensive literatures, relatively little attention has been paid to the role of religion in liberal or progressive politics. These efforts are more widespread and more racially, socioeconomically and religiously diverse than is typically recognized. Moreover, while these actors seek influence within the most visible political realms of elections and policymaking, they also focus on shaping the cultural identities, narratives and discourses that undergird democratic life. This article offers a framework through which to conceptualize the progressive religious field of action, and reviews the growing body of research on the individuals and organizations that comprise this field. It begins by examining the prevalence of progressive religious views and activities among the general public; reviews research on three different types of progressive religious political organizations - national advocacy organizations, social movements, and faith-based community organizations - as well as religious congregations' efforts to spur members to political consciousness and mobilization; and evaluates the place of progressive religion in American political culture. Finally, it points to fruitful areas for future research.
\end{abstract}

\section{Introduction}

In recent years, scholars interested in the role of religion in American political life have largely focused on the Christian Right, a movement that rocketed to national political influence in the early 1980s. Yet a focus on the role of religion in conservative politics overlooks a wide range of other ways in which religion enters public life. For example, in local communities across the country, religious congregations and other faith-based organizations provide social services (Wuthnow 2006); supply citizens with civic skills (Verba, Schlozman, and Brady 1995); and encourage citizens to develop social capital (Lichterman 2005; Lichterman and Potts 2008; Putnam and Campbell 2010). Religion also plays a prominent role within many immigrant communities (Foley and Hoge 2007; Numrich and Kniss 2007). These diverse phenomena have been well-documented, yet they are typically considered "civic" rather than "political."

Compared to these extensive literatures, relatively little attention has been paid to the role of religion in liberal or progressive politics. Work on the role of the Black Church in the civil rights movement (e.g., Morris 1984) and, to a lesser extent, on anti-war activism and the 
farmworkers' movement during the 1970s (Cox 1967; Hadden 1969; McNamara 1969), represent important exceptions. That said, by relying on these earlier movements (especially the civil rights movement) as templates for how religion can be marshaled to the cause of social, economic and racial justice, we miss the large variety of ways that religion figures in progressive politics - historically and today. These efforts are more widespread and more socially (and religiously) diverse than is typically recognized. They also seek influence beyond the most visible political realms of elections and policymaking, focusing as much if not more on shaping the cultural identities, narratives and discourses that undergird democratic life.

While there have certainly been periods when progressive religious voices have been drowned out by louder and more visible actors - on both the religious Right and the secular left at other times progressive religious voices have been impossible to ignore, and millions have mobilized in answer to their call to action. This article reviews the growing body of research on this field of action, offers a framework through which to conceptualize connections between these varied efforts, and points to fruitful areas for future research.

\section{A progressive religious field of action}

First, however, it is necessary to acknowledge that many religious groups and individuals avoid calling themselves "liberal," "progressive," or "left-wing" even while participating in social action that could mark them as such. Others may embrace aspects of a progressive agenda even as they also promote certain beliefs or engage in practices commonly identified as conservative. This lack of a clearly bounded category of social actors that identify as religious progressives poses analytic challenges to studying this phenomenon. 
As an alternative, we conceptualize our object of study as a progressive religious field of action. By this we mean "a set of individuals and organizations that are defined by knowledge of each other, relationships to shared discourses, symbols and historical referents, and a shared orientation toward a set of common stakes and overlapping values, such as social justice, peace, community, equality, and the common good" (Fuist, Braunstein, and Williams 2017:12). Importantly, the field is also defined in part through efforts to distinguish itself from other fields of action, namely, the conservative religious and secular progressive fields.

The diverse set of individuals and groups who comprise the progressive religious field tend to have one of the following characteristics (Fuist, Braunstein, and Williams 2017).

- Progressive action: They participate in social action oriented toward greater economic, political, and/or social equality_including anti-poverty activism or mobilization around the issue of universal health care.

- Progressive values: They espouse a commitment to reform-oriented change and/or social justice_-including anti-racist or feminist values.

- Progressive identities: They consciously identify with other groups and individuals generally viewed as religious progressives - for example, by hanging pictures of Martin Luther King, Jr., in its meeting space or understanding oneself as connected to the peace movement.

- Progressive theology: They engage in efforts to deconstruct, reform, or challenge faith traditions toward the end of making them more inclusive or just—-for example, by promoting Biblical feminism, queer theology, Latin American liberation theology or antiracist theology.

While these qualities are connected and often bundled together, they are not inherently a 
complete package, and may appear in various combinations in different groups.

Guided by this conceptualization of progressive religious action, we identify several ways in which the individuals and groups that comprise this field seek to influence American politics and culture. We begin by examining the prevalence of progressive religious views and activities among the general public. We then review research on three different types of progressive religious political organizations - national advocacy organizations, social movements, and faithbased community organizations - as well as congregations' efforts to spur members to political consciousness and mobilization. Finally, we evaluate the place of progressive religion in American political culture.

\section{Progressive religion among the public}

As Wuthnow (1988) documented thirty years ago, American religion "restructured" along a liberal/conservative axis following the 1960s. Major social divisions that ran along denominational or faith tradition lines became less significant than a cross-cutting cleavage that separated liberals from conservatives within each faith tradition. Liberal Protestants came to share more with liberal Catholics than they did with conservative Protestants. Certainly, that division can be seen in many attitudinal measures, such as those indicating support for women's reproductive rights or immigration policy. This restructuring was largely driven by differences in education levels, region of the country, urban versus small town/rural residence, and occupation in "knowledge" industries.

What has not been as well recognized in much of this literature is the extent the liberal/conservative axis also has gendered and racialized components - women are more liberal than men in most categories, and ethnic and racial minority Protestants and Catholics are 
consistently liberal on economic and political issues, if not always on all gender and sexuality concerns (e.g., McDaniel 2016). Public opinion research largely bears this out. During the last three decades, white evangelical Protestants have become increasingly Republican, and remain more conservative than most groups on issues of gender, sexuality, and family. Mormons look much the same. Roman Catholics are evenly divided between the major political parties, with white, non-Hispanic Catholics more likely to be Republican, and Hispanic and other Catholics of color more likely to be Democratic. White mainline Protestants are generally "socially liberal" and moderate on economic issues - and in 2008 became more likely to identify as Democrats than Republicans for the first time since the New Deal (Smidt et al. 2010), and Jews are consistently liberal (with the notable exception of a conservative stance on Israel). Other faith traditions - whether because they are politically diverse or because their members are relative newcomers to U.S. politics - do not (yet) have clearly defined political profiles.

As the Republican Party solidified its support among white evangelical Protestants and many white Catholics, two decades of scholarly attention went to the attitudinal determinants of the conservative religion-politics nexus. While remaining rooted in gender, sexuality, and family issues, religiosity measures such as weekly worship service attendance and belief in biblical literalism were revealed to be the best predictors of Christian Right orientation. However, attendance and literalism are themselves declining in American religion (see Chaves 2017). Much of this decline has come from people who have grown tired of the tight connection between conservative religion and Republican politics, and there is evidence that this weariness has also contributed to the rise of religious "nones" (Hout and Fisher 2002, 2014).

As a result, some analysts see an opening for a resurgent religious Left. Various demographic, political, and cultural changes since the turn of the century (e.g., Dionne 2008; 
Jones et al. 2013) may well have opened the door to an increasing association between religious commitments and liberal political attitudes and voting, and increasing identification between religion and progressive values. As Petz and Smidt (2015) document, President Obama inspired younger voters, including white evangelicals, to support a more progressive political outlook (see also, Rhodes 2011). This was perhaps most visible in the declining opposition to same-sex marriage among younger people (e.g., Perry and Whitehead 2016; Walls et al. 2014). Further, many younger religious cohorts, especially among Catholics, are sympathetic to immigrant rights and are alienated by the GOP Right's hardline on that issue. In sum, the attitudinal landscape has become increasingly fractured across the American religious public except on the Christian Right, and easy associations among religious tradition, identity, or practices and political opinions miss important distinctions.

Yet it is unclear whether the growing number of individuals who hold progressive religious views could coalesce into a progressive religious movement capable (narrowly) of offsetting the power of the religious Right or (more broadly) of providing Americans an alternative way of imagining the role of religion (and God) in their efforts to "forge a common life" (Bretherton 2014). The religious Left is fairly inchoate, with a broad agenda, and tenuous ties to the Democratic party (Sullivan 2008; Olson 2017; Sager 2017). It also includes a socially, religiously and politically diverse set of constituencies who do not just tolerate, but actively celebrate, differences in opinion (Alpert 2000; Kellstedt et al. 2007; Olson 2011). Despite these challenges, a large number of organizations and leaders are working - often below scholars' and the media's radar - to lift up the voices and values of Americans who are progressive and religious. 


\section{Social movement activism}

Despite the visibility of the Christian Right, religious activists have consistently mobilized for progressive causes through U.S. history. Broadly speaking, religion has factored into progressive mobilization in three key ways: by (1) serving as a tangible resource, (2) shaping the motivations, ideologies, practices, and identities of participants, and (3) granting a source of moral authority.

When Rosa Parks was arrested for refusing to give up her bus seat in 1955, E.D. Nixon, head of the local NAACP, called a meeting to plan a boycott. It was no accident that the meeting took place in a church and drew on the networks of local ministers because churches have consistently provided tangible resources that movements need to mobilize (Morris 1984). In the civil rights movement, black congregations offered space for meetings, dense networks that helped spread information, and paid staff who could dedicate time to activism (Harris 1999; Morris 1984). Similarly, religious groups played a "movement midwife" role in the Central American peace movement by raising money and serving as "feeder organizations" (Smith 1996). Congregations were able to use their extensive networks to publicize movement concerns and, in several cases, "entire congregations would vote to become involved in refugee work" drawing "tens of thousands of Americans... into the Central American peace movement" (Smith 1996:113). Meanwhile, the New Sanctuary Movement has used church space to, in some cases, literally house immigrants in danger of deportation (Yukich 2013), while progressive faith-based community organizing groups have made extensive use of the resources provided by member congregations in their advocacy work (Wood and Fulton 2015; Geraty 2017).

Churches, however, have provided more than meeting space and money for movements. As Pattillo-McCoy (1998) notes, the "importance of the black church lies not only in its 
organizational ability...but also in its cultural strength as a common language that leaders and followers...can share to coordinate action" (781). Religious languages have been used to frame and motivate progressive activism throughout U.S. history in movements as diverse as the eighthour movement (Mirola 2015), LGBT rights (Wilcox 2003), and women's suffrage (McKanan 2011). For example, Martinez (2017) documents the intertwining of immigrant rights activism and Christian imagery during a Posadas event (a ritual observed by Mexican Catholics that reenacts the story of the Holy Family). The Posadas procession Martinez attended had speakers who directly tied the story of the Holy Family to the plight of undocumented immigrants. The Plowshares movement, similarly, has drawn on understandings of Christian sacrifice and righteousness to motivate high-risk activism. Nepstad (2008) finds that the shared religious understandings of the Plowshares movement created trust between participants necessary to plan and undertake actions that would almost certainly result in arrest, such as breaking into missile silos.

Third, because religious groups in the U.S. are "perceived as the 'carriers of the moral' in the culture," their claims to moral authority tend to be more persuasive than those of other kinds of groups (Williams and Demerath 1991:419). While Hart (2001) has argued that progressives often lack a transcendent, moral language when communicating their ideologies, Fuist (2017) demonstrates that progressive religious groups are able to blend the moral language of religion with left-wing structural critique. As Tobey's (2016) research shows, the aforementioned Plowshares movement base their audience-conscious actions on a self-understanding of "moral distinction" that "sets them apart from a war-making state, a complicit Church, and an apathetic society" (5-6). Braunstein (2012), similarly, shows how liberal religious activists deliberately highlight their connections to faith communities to demonstrate that, as religious citizens, they 
are "properly distanced from interest group politics, yet able to provide decisionmakers with direct access to information culled from the faith communities they represent" (117). It is worth noting, though, that the moral legitimacy granted religious activists is highly contingent upon their religious and racial identities — while white Christian faith leaders and communities are framed as neutral and disinterested moral arbiters, non-Christian faith leaders and people of color are often viewed with suspicion or as motivated by more "base" political or economic interests when they enter public life (Edgell 2017; Yukich 2017).

\section{National advocacy organizations}

While liberal religious advocacy organizations often support the work of social movements, they occupy an organizational field whose features shape their broader efforts in important ways. These organizations, which include membership-based advocacy organizations; the Washington offices of liberal denominations; faith-based service agencies; and national networks of congregation-based community organizations, participate in the competitive field of interest group politics in Washington, DC, where they bring varied faith perspectives to bear on policymaking debates. They do so by lobbying for public policies that are consistent with their communities' religious values or with values that are broadly shared across multiple faith communities, like peace, social justice, or the common good. Many also seek to mobilize grassroots support for their efforts, by engaging in public campaigns that highlight the moral valence of issues and calling upon people of faith to pressure their representatives (Hertzke 1988; Wuthnow 1988; Hofrenning 1995; Yamane 2005; Fowler et al. 2013).

Although the national policymaking field is dominated by technical experts and moneyed interests (Schlozman, Verba, and Brady 2012), many religious groups play a role in many policy 
debates, thanks to their aforementioned reputation as the "carriers of the moral" in American society (Williams and Demerath 1991). Their moral authority on issues of public concern is not only dependent on the values, lessons, and stories they draw from their religious traditions. It is also rooted in their structural position as "outsiders" who in theory lack a material interest in the outcomes of policies (Williams and Demerath 1991); as well as their status as representatives of large number of citizens and carriers of local knowledge about how policies are experienced within local communities (Braunstein 2012).

Because these advocates justify their existence by reference to the authenticity and distinctiveness of their religious voices (Moody 2002; Olson 2002), they are mindful of the need to communicate in ways that both highlight their religious identities, but also conform to the secular speech norms of the "lobby craft" (Hertzke 1988:88), ${ }^{1}$ and build broad interfaith support for their positions (Lichterman 2005; Wood 2002). To this end, they have developed various solutions to these challenges. For example, Braunstein $(2012 ; 2017)$ shows how the Nuns on the Bus campaign and other similar organizations use "secular" storytelling to broaden the appeal of their claims even as they maintain the moral force of religious authority. Similarly, Fuist (2017) demonstrates that the "moral talk" used by advocacy groups establishes different "models" for understanding connections between faith with social justice efforts, making the religio-moral authority clear, even as it de-centers specific sectarian arguments. Finally, Gorski (2017a,b) argues that civil religion offers a means of marshalling religion's prophetic power in a way that is inclusive and widely accessible.

\section{Faith-based community organizing}

\footnotetext{
${ }^{1}$ Policymaking here must be distinguished from politics, in which religious expression is encouraged and commonplace. But a line is typically drawn between the two-in theory, if not in practice.
} 
Occupying a niche position between social movements and relatively enduring civic/political organizations, faith-based community organizing (FBCO) networks bring congregations and other local institutions together to train local leaders equipped to advocate for policies that better serve their communities. The national field of faith-based community organizing coalitions represents one of the largest and most diverse grassroots movements for social justice today (Wood and Fulton 2015; Fulton and Wood 2017). Indeed, a 2011 census of FBCO coalitions operating nationwide found that this field as a whole represented over 5 million people, up from around 2 million in 2001 (Wood, Fulton and Partridge 2011). Major national coalitions include the PICO National Network (People Improving Communities through Organizing), the Industrial Areas Foundation, and DART (the Direct Action and Research Training Center).

Over the past two decades, this field has received increased attention from scholars, who along with practitioners within the field (e.g., Jacobsen 2001; Chambers and Cowan 2003; Gecan 2004; Whitman 2018), have documented these organizations' unprecedented successes in a range of policy areas (Wood and Fulton 2015). At the same time, however, they have also had to overcome a variety of challenges arising from their structure and vision. First, because FBCOs are primarily comprised of "ordinary" people, they invest in developing these leaders' political confidence, skill, and subjectivity (Stout 2010; Han 2014; Oyakawa 2015; Braunstein 2017). Especially for members of marginalized or oppressed groups, FBCOs are spaces in which to develop empowering "redemption scripts" (Flores and Cossyleon 2016). They also encourage participants to expand their "collective moral imaginary" (Delehanty and Oyakawa 2017) in a manner that helps them determine how their self-interest intersects with the common good of their diverse communities (Delehanty 2016; Braunstein 2017). 
Second, most FBCO leaders are not experts in the technicalities of public policies, despite having significant knowledge about policies' impacts on their communities. As such, they have developed creative ways of communicating this well of local and experiential knowledge, often through ritualized storytelling performances, intended to deepen the understanding and tug at the heartstrings of decision-makers. During these "public accountability actions," often held within places of worship and in front of large crowds of witnesses, FBCO leaders then demand commitments from public officials and other elites to address their concerns. Along with other tactics, these practices are central to FBCOs' efforts to hold elites accountable to ordinary people, a condition they view as necessary for a healthy democracy (Stout 2010; Wood and Fulton 2015; Braunstein 2017).

Third, although FBCOs primarily focus on reigning in growing power imbalances between ordinary citizens and elites, they must also work to limit power imbalances within their own coalitions. Indeed, such imbalances are common within organizations that exhibit high levels of racial, ethnic, and socioeconomic diversity, like most FBCOs (Wood, Fulton, and Partridge 2012; Wood and Fulton 2015; Geraty 2017). If left unchecked, these imbalances can fuel distrust and disagreement. As a result, many FBCOs emphasize their equality and shared values as "people of faith." They reinforce this identity by drawing heavily on religion to build shared group identities and cultures (Hart 2001; Swarts 2008; Stout 2010; Wood 1999, 2002); developing "bridging cultural practices" - like interfaith prayers - that emphasize their commonalities as "people of faith" while downplaying or celebrating their other differences (Braunstein, Fulton and Wood 2014; see also Warren 2001); or cultivating a "multicultural activist etiquette" intended to make all parties feel safe, equal and included (Diaz Edelman 2017). 
Overall, scholars have expressed enthusiasm about FBCOs' capacity to "revitalize" democracy (Warren 2001); to be the future of "progressive politics in America" (Osterman 2003; see also Hart 2001); to cultivate a distinctive model of grassroots democracy (Stout 2010) or active citizenship (Braunstein 2017); and to promote racial and economic justice (Wood and Fulton 2015). Interest in FBCOs also continues to grow—among scholars of religion and theology who see in FBCOs a sophisticated example of religious ethics in action (e.g., Snarr 2011; Bretherton 2014; Lloyd 2014); as well as participants in the Trump resistance movement who see in FBCOs a powerful model for holding elites accountable (Whitman 2018).

\section{Religious congregations}

In quieter and less overly "political" ways, religious congregations are also fertile ground in which progressive religious politics can grow. While denominations were once the boundary markers of American religion, they have declined in significance compared to a liberalconservative divide that cuts across denominations (Wuthnow 1988). Congregations have thus become, for many Americans, a site where politics are regularly debated and enacted. In countless congregations in the U.S., we can see this play out in two key ways: (1) in the conversations that happen within congregations about progressive issues, and (2) in how congregations organize and act on behalf of progressive causes.

Many congregations encourage discussions that shape members' perceptions about progressive causes, including immigrant rights (Yukich 2013; Adler 2017) and racial equality (Marti 2005). As Mundey et al. (2011) demonstrate, congregational cultures can sacralize acts and issues through how they frame them to their members. As such, when congregational leaders or participants talk about economic equality as God-ordained (Fuist 2017) or immigrant rights as 
sacred (Martinez 2017), they provide cultural resources to members that can promote progressive action. For example, research links debates about LGBT issues within congregations to an increase in LGBT acceptance and inclusion (Cadge, Day, and Wildeman 2007). In some cases, ostensibly "straight" congregations have had ongoing conversations about how to best practice their desire to be inclusive while also adhering to their perceptions of scripture (Moon 2004); in others, members have embraced being "welcoming and affirming” to LGBT persons, while still promoting and enacting Christian understandings of monogamy and gender (McQueeney 2009). Conversely, as an outgrowth of the LGBT rights movement, the Metropolitan Community Church denomination, and many congregations within other traditions, actively identify as LGBT churches (Wilcox 2003). These congregations may promote queer theologies that demonstrate alternative applications of faith traditions to issues of sexuality, politics, and gender, shaping how participants understand and behave as queer persons of faith (Fuist 2016; Dillon 1999).

Many progressive congregations also go beyond discussion, by organizing to take collective action. Only a relatively small fraction of congregations report being involved in progressive religious political activities (Beyerlein and West 2017), but self-identified liberal congregations engage in more service-based action than conservative congregations (Chaves and Tsitsos 2001), and Catholics, black Protestants, and mainline Protestants tend to be more civically engaged than conservative Protestants (Ammerman 2002; Beyerlein and Hipp 2006). While churches of all persuasions connect with non-profit groups, progressive churches are also more likely than conservative congregations to partner with secular groups, expanding their ability to foster "bridging social capital" within their communities (Ammerman 2002; Beyerlein and Hipp 2006; Lichterman 2005). Taken together, congregations involve themselves in public 
life in a variety of ways, including talking about progressive politics in a way that shapes the understandings and actions of members, and serving as a site through which members can coordinate public actions (Beyerlein and West 2017).

\section{American political culture}

American ideas about politics are embedded in a religious history and worldview (Mead 1985; Harrington 1986; Williams 1999; McKenna 2007). In many parts of Western Europe and Latin America, progressive politics came with an inherent anti-clericalism. To be progressive was to be (and often still is) secular. Not so the United States. The nation's cultural grounding in a mix of liberalism, Calvinist Protestantism, and civic republicanism (see, e.g., Bellah et al. 1985) has kept a place for religion, even in the midst of political and economic reforms. Protestantism continues to enjoy a privileged place in that cultural heritage, but American political culture remains open to a diverse range of religious worldviews, ideas, and actors.

Progressive religious activists can thus draw heavily from theological and doctrinal resources when engaging in politics: they cite Hebrew prophets speaking truth to power, Jesus overturning the money-changers' table in the temple, and the turn-of-the-century's "Social Gospel." These religious stories, symbols and ideas are a key part of the "cultural repertoire" (Williams 1995) that gives Americans a language and a set of symbols to think and talk about politics. In addition to these explicit religious references, many of the ideas common to American political culture have deep associations with religious worldviews and teachings that are less apparent. For example, the idea of individual dignity as a political principle emerged in Enlightenment philosophy, but has also been a feature of a number of Christian doctrines (Wood 2014). So, too, ideas about equality — when groups such as the Quakers, and many in the 
Anabaptist tradition, extended their conceptions of the Christian soul across racial lines, this formed some of the bedrock of abolitionist sentiment and action (e.g., Smith 1997; Young 2006). While classical liberalism did not need an immanent God for its conception of a well-ordered society, there was nonetheless an elective affinity between Protestantism and emerging liberal thought in England, Scotland, and the Netherlands. Without a clerical establishment in colonial America, a political culture developed in which religion and progressive political notions could coexist. As Siedentop argues, "liberalism rests on the moral assumptions provided by Christianity" (2014: 338). There is a case to be made that there is no significant American political language that is completely secular-indeed, even socialism in America was intertwined with religion (consider Robert Owen's New Harmony, Indiana, or Dorothy Day’s Catholic Worker).

The most significant articulation of religion's place in American political culture is found in the concept of "civil religion." First applied to the U.S. by Bellah $(1967,1975)$ the idea posited a generalized cultural understanding that linked the nation's history, identity, and destiny to Providence and Divine favor. Importantly, Bellah's civil religion was prophetic, insofar as it provides transcendent standards for the good society, to which the nation is accountable. Thus, civil religion is a resource for critiques of the extant, toward a more just and inclusive future (see also Gorski 2017a,b). While Bellah was keenly aware of the founding "sin" of slavery in the U.S., he saw in civil religion a way to challenge and eventually transcend racial injustice. American civil religious language has proved a useful resource for many progressive movements (e.g., Braunstein 2017a; Williams and Alexander 1994; Flores and Cossyleon 2016; Reed, et al. 2016).

\section{Where do we go from here?}


This article reviews the growing body of research on religion and progressive politics, and situates this work within its historical and scholarly context. Despite a recent uptick in interest in this subject, however, many questions remain unanswered, and relevant theories - of social movements, civic and political action, religion and democracy, etc. - will need to be revised in light of new findings.

This review has focused on the U.S., a political context in which public religion has, in recent decades, been monopolized by religious conservatives. While this has contributed to the overshadowing of the progressive religious field in the U.S., we do not wish to convey this is necessarily the case elsewhere. Moreover, many religious advocacy and activist organizations transcend national borders, requiring researchers to be attuned to both the contours of each national political field in which they are engaged, as well as broader transnational field in which these organizations are embedded (e.g., Nepstad 2004; Bandy and Smith 2005). In each case, it would be a mistake to impose upon these other sites the American political categories and historical reference points we have discussed. Scholarship on religion and American politics has historically benefitted from engagement with the large body of research that exists on the intersection of religion and politics outside of the U.S. (e.g., Smith 1996), as well as through more structured comparisons of "public religion" in the US and elsewhere (e.g., Casanova 1994; Mayrl 2017; Nepstad 2017). The more general takeaway is that theory building about the relationship between religion and politics should keep this global dimension in mind.

So too should researchers stay connected to the growing body of scholarship on the history of progressive religion in the U.S. and around the world. In recent years, mirroring developments within the sociology of religion, historians and historical sociologists have become increasingly interested in this subject, examining historical precursors of contemporary 
progressive religious movements (e.g., Swartz 2014); the previously unrecognized religious roots of social movements (e.g., Young 2002; Gahr and Young 2017); and the complex interplay between religion and class in the development of progressive, radical and populist politics (e.g., Calhoun 2012; Carter 2015; Cantwell et. al 2016).

Finally, while the scholars mentioned in this essay have made significant headway mapping this field and its contours, work is also underway to identify emerging conceptual blind spots - some of which also impact the progressive religious field itself. For example, much of this research is conducted in or around religious congregations. While this reflects the central role congregations play in these efforts, it also leads researchers to overemphasize the political action of groups who are most comfortable with congregation-based political talk and organizing (namely, Christian and Jewish communities), and to ignore those groups who are not (including many new immigrant communities, like Muslims, Hindus, and Buddhists) (Yukich 2017).

Similarly, the ways in which researchers conceptualize "religion" will impact what "counts" as religious-based political action. To the extent this definition emphasizes religious organizations and leaders or identification with religious traditions, researchers will miss more subtle ways in which religious and more vaguely "spiritual” ideas, ideals, practices, values, and subjectivities infuse political action (e.g., Stanczak 2006). This is especially important as the U.S. witnesses a historic spike in the number of religious "nones," who are rethinking what it means to be religious, to be political, and to combine these in practice (Hout and Fischer 2002, 2014), perhaps via a "new sacred politics" (Lloyd 2017). Critical reflections on these blind spots will not only advance our empirical knowledge, but also our capacity to build more general theoretical insights, toward the end of better understanding the American political landscape.

\section{References}


Adler, Jr., Gary J. 2017. “"Neutral” Talk in Educating for Activism.” Pp. 308-27 in Religion and Progressive Activism: New Stories about Faith and Politics, edited by Ruth Braunstein, Todd Nicholas Fuist, and Rhys H. Williams. New York: NYU Press.

Alpert, Rebecca T., ed. 2000. Voices of the Religious Left: A Contemporary Sourcebook. Philadelphia: Temple University Press.

Ammerman, Nancy Tatom. 2002. “Connecting Mainline Protestant Congregations with Public Life." Pp. 129-158 in The Quiet Hand of God: Faith Based Activism and the Public Role of Mainline Protestantism, edited by Robert Wuthnow and John H. Evans. Berkeley: University of California Press.

Bandy, Joe, and Jackie Smith. 2005. Coalitions Across Borders: Transnational Protest and the Neoliberal Order. Rowman \& Littlefield.

Bellah, Robert N. 1967. “Civil Religion in America.” Daedalus 96 (1): 1-21.

Bellah, Robert N. 1975. The Broken Covenant: American Civil Religion in Time of Trial. New York: Seabury Press.

Bellah, Robert N., Richard Madsen, William M. Sullivan, Ann Swidler, and Steven M. Tipton. 1985. Habits of the Heart: Individualism and Commitment in American Life. Berkeley: University of California Press.

Beyerlein, Kraig and A. Joseph West. 2017. "Why Congregations Mobilize for Progressive Causes." Pp. 76-96 in Religion and Progressive Activism: New Stories About Faith and Politics, edited by Ruth Braunstein, Todd Nicholas Fuist, and Rhys H. Williams. New York: New York University Press. 
Beyerlein, Kraig and John R. Hipp. 2006. "From Pews to Participation: The Effect of Congregation Activity and Context on Bridging Civic Engagement." Social Problems (53)1: 97-117.

Braunstein, Ruth, Brad R. Fulton, and Richard L. Wood. 2014. "The Role of Bridging Cultural Practices in Racially and Socioeconomically Diverse Civic Organizations." American Sociological Review 79 (4): 705-25.

Braunstein, Ruth, Todd Nicholas Fuist, and Rhys H. Williams, eds. 2017. Religion and Progressive Activism: New Stories about Faith and Politics. New York: NYU Press. Braunstein, Ruth. 2012. "Storytelling in Liberal Religious Advocacy." Journal for the Scientific Study of Religion 51 (1): 110-27.

Braunstein, Ruth. 2017a. Prophets and Patriots: Faith in Democracy across the Political Divide. Braunstein, Ruth. 2017b. "Strategic Storytelling by Nuns on the Bus." Pp. 289-307 in Religion and Progressive Activism: New Stories about Faith and Politics, edited by Ruth Braunstein, Todd Nicholas Fuist, and Rhys H. Williams. New York: NYU Press.

Bretherton, Luke. 2014. Resurrecting Democracy: Faith, Citizenship, and the Politics of a Common Life. Cambridge University Press.

Cadge, Wendy, Heather Day, and Christopher Wildeman. 2007. "Bridging the DenominationCongregation Divide: Evangelical Lutheran Church in America Congregations Respond to Homosexuality." Review of Religious Research 48 (3): 245-59.

Calhoun, Craig. 2012. The Roots of Radicalism: Tradition, The Public Sphere and Early Nineteenth-Century Social Movements. Chicago, IL: University of Chicago Press. 
Cantwell, Christopher D., Heath W. Carter, and Janine Giordano Drake, eds. 2016. The Pew and the Picket Line: Christianity and the American Working Class. Urbana, Chicago: University of Illinois Press.

Carter, Heath W. 2015. Union Made: Working People and the Rise of Social Christianity in Chicago. New York: Oxford University Press.

Casanova, José. 1994. Public Religions in the Modern World. Chicago: University of Chicago Press.

Chambers, Edward T. 2003. Roots for Radicals: Organizing for Power, Action, and Justice. First Edition. New York: Bloomsbury Academic.

Chaves, Mark and Willaim Tsitsos. 2001. "Congregations and Social Services: What They Do, How They Do It, and With Whom." Nonprofit and Voluntary Sector Quarterly 30: 660683.

Chaves, Mark. 2017. American Religion: Contemporary Trends. Second Edition. Princeton, NJ: Princeton University Press.

Cox, Harvey. 1967. “The 'New Breed' in American Churches: Sources of Social Activism in American Religion.” Daedalus 96 (1): 135-150

Delehanty, Jack, and Michelle Oyakawa. 2017. "Building a Collective Moral Imaginary: Personalist Culture and Social Performance in Faith-Based Community Organizing." American Journal of Cultural Sociology, 1-30.

Delehanty, John D. 2016. "Prophets of Resistance: Social Justice Activists Contesting Comfortable Church Culture.” Sociology of Religion 77 (1): 37-58.

Diaz-Edelman, Mia. 2017. “Activist Etiquette in the Multicultural Immigrant Rights Movement." Pp. 138-60 in Religion and Progressive Activism: New Stories about Faith and Politics, 
edited by Ruth Braunstein, Todd Nicholas Fuist, and Rhys H. Williams. New York: NYU Press.

Dillon, Michele. 1999. Catholic Identity: Balancing Reason, Faith and Power. New York: Cambridge University Press.

Dionne, E. J. Jr. 2009. Souled Out: Reclaiming Faith and Politics after the Religious Right. Princeton, NJ: Princeton University Press.

Edgell, Penny. 2017. “An Agenda for Research on American Religion in Light of the 2016 Election." Sociology of Religion 78 (1): 1-8.

Flores, Edward Orozco, and Jennifer Elena Cossyleon. 2016. “'I Went Through It so You Don’t Have To': Faith-Based Community Organizing for the Formerly Incarcerated.” Journal for the Scientific Study of Religion 55 (4): 662-76.

Foley, Michael W., and Dean R. Hoge. 2007. Religion and the New Immigrants: How Faith Communities Form Our Newest Citizens. Oxford University Press.

Fowler, Robert Booth, Allen D. Hertzke, Laura R. Olson, and Kevin R. den Dulk. 2014. Religion and Politics in America: Faith, Culture, and Strategic Choices. 5th edition. Boulder, Colorado: Routledge.

Fuist, Todd Nicholas, Laurie Cooper Stoll, and Fred Kniss. 2011. "Beyond the LiberalConservative Divide: Assessing the Relationship Between Religious Denominations and Their Associated LGBT Organizations." Qualitative Sociology 35 (1): 65-87.

Fuist, Todd Nicholas, Ruth Braunstein, and Rhys H. Williams. 2017. “Introduction: Religion and Progressive Activism-Introducing and Mapping the Field." Pp. 1-26 in Religion and Progressive Activism: New Stories about Faith and Politics, edited by Ruth Braunstein, Todd Nicholas Fuist, and Rhys H. Williams. New York: NYU Press. 
Fuist, Todd Nicholas. 2016. “'It Just Always Seemed Like it Wasn't a Big Deal, Yet I Know for Some People They Really Struggle with It': LGBT Religious Identities in Context. Journal for the Scientific Study of Religion 55(4): 770-86.

Fuist, Todd Nicholas. 2017. "How Moral Talk Connects Faith and Social Justice.” Pp. 328-47 in Religion and Progressive Activism: New Stories about Faith and Politics, edited by Ruth Braunstein, Todd Nicholas Fuist, and Rhys H. Williams. New York: NYU Press.

Fulton, Brad R, and Richard L. Wood. 2017. "Achieving and Leveraging Diversity through Faith-Based Organizing.” Pp. 29-55 in Religion and Progressive Activism: New Stories about Faith and Politics, edited by Ruth Braunstein, Todd Nicholas Fuist, and Rhys H. Williams. New York: NYU Press.

Gahr, Joshua Z., and Michael P. Young. 2017. “Religious Roots of New Left Radicalism.” Pp. 183-204 in Religion and Progressive Activism: New Stories about Faith and Politics, edited by Ruth Braunstein, Todd Nicholas Fuist, and Rhys H. Williams. New York: NYU Press.

Gecan, Michael. 2004. Going Public: An Organizer's Guide to Citizen Action. New York: Anchor Books.

Geraty, Kristin. 2017. “Challenges and Opportunities of Community Organizing in Suburban Congregations.” Pp. 161-80 in Religion and Progressive Activism: New Stories about Faith and Politics, edited by Ruth Braunstein, Todd Nicholas Fuist, and Rhys H. Williams. New York: NYU Press.

Gorski, Philip. 2017a. American Covenant: A History of Civil Religion from the Puritans to the Present. Princeton, NJ: Princeton University Press. 
Gorski, Philip. 2017b. "Reviving the Civil Religious Tradition.” Pp. 271-288 in Religion and Progressive Activism: New Stories about Faith and Politics, edited by Ruth Braunstein, Todd Nicholas Fuist, and Rhys H. Williams. New York: NYU Press.

Guth, James L., Lyman A. Kellstedt, Corwin E. Smidt, and John C. Green. 1993. “Theological Perspectives and Environmentalism among Religious Activists." Journal for the Scientific Study of Religion 32 (4): 373-382.

Hadden, Jeffrey K. 1969. The Gathering Storm in the Churches. Garden City, NJ: Doubleday. Han, Hahrie. 2014. How Organizations Develop Activists: Civic Associations and Leadership in the 21st Century. Oxford University Press.

Harrington, Mona. 1986. The Dream of Deliverance in American Politics. New York: Alfred Knopf.

Harris, Fredrick. 1999. Something Within. Oxford University Press.

Hart, Stephen. 2001. Cultural Dilemmas of Progressive Politics: Styles of Engagement Among Grassroots Activists. Chicago: University of Chicago Press.

Hertzke, Allen D. 1988. Representing God in Washington: The Role of Religious Lobbies in the American Polity. 1st ed. Knoxville: University of Tennessee Press.

Hofrenning, Daniel J. B. 1995. In Washington but Not of It: The Prophetic Politics of Religious Lobbyists. Philadelphia: Temple University Press.

Hout, Michael, and Claude S. Fischer. 2002. "Why More Americans Have No Religious Preference: Politics and Generations.” American Sociological Review 67 (2): 165-90. Hout, Michael, and Claude S. Fischer. 2014. "Explaining Why More Americans Have No Religious Preference: Political Backlash and Generational Succession, 1987-2012.” Sociological Science 1: 423-47. 
Jacobsen, Dennis A. 2001. Doing Justice: Congregations and Community Organizing, 1st Edition. 1 edition. Minneapolis: Fortress Press.

Jones, Robert P. 2017. The End of White Christian America. Reprint edition. New York: Simon $\&$ Schuster.

Jones, Robert P., Daniel Cox, E.J. Dionne Jr., William A. Galston, and Juhem Navarro-Rivera. 2013. "Do Americans Believe Capitalism \& Government Are Working?: Religious Left, Religious Right \& the Future of the Economic Debate.” PRRI. https://www.prri.org/research/economic-values-survey-07-2013/.

Kellstedt, Lyman A., Corwin E. Smidt, John C. Green, and James L. Guth. 2007. "A Gentle Stream or a 'River Glorious'? The Religious Left in the 2004 Election.” Pp. 232-56 in $A$ Matter of Faith: Religion in the 2004 Presidential Election, edited by David E. Campbell. Washington, DC: Brookings Institution.

Lichterman, Paul, and C. Brady Potts. 2008. The Civic Life of American Religion. Stanford University Press.

Lichterman, Paul, and Rhys H. Williams. 2017. "Cultural Challenges for Mainline Protestant Political Progressives.” Pp. 117-37 in Religion and Progressive Activism: New Stories about Faith and Politics, edited by Ruth Braunstein, Todd Nicholas Fuist, and Rhys H. Williams. New York: NYU Press.

Lichterman, Paul. 2005. Elusive Togetherness: Church Groups Trying to Bridge America's Divisions. Princeton, NJ: Princeton University Press.

Lloyd, Vincent. 2014. “Organizing Race.” Journal of Religious Ethics 42 (4): 640-60. 
Lloyd, Vincent. 2017. "MLK Day and the Emergence of the New 'Sacred Politics."” Political Theology Today. http://www.politicaltheology.com/blog/mlk-day-and-the-emergence-ofthe-new-sacred-politics-vincent-lloyd/.

Marti, Gerardo. 2005. A Mosaic of Believers: Diversity and Innovation in a Multiethnic Church. Bloomington, IN: Indiana University Press.

Martinez, Juan R. 2017. "Religious Culture and Immigrant Civic Participation.” Pp. 205-224 in Religion and Progressive Activism: New Stories About Faith and Politics, edited by Ruth Braunstein, Todd Nicholas Fuist, and Rhys H. Williams. New York: NYU Press.

Marvin, Carolyn and David W. Ingle. 1996. "Blood Sacrifice and the Nation: Revisiting Civil Religion." Journal of the American Academy of Religion 64(4):767-80.

Mayrl, Damon. 2016. Secular Conversions: Political Institutions and Religious Education in the United States and Australia, 1800-2000. Cambridge, United Kingdom; New York: Cambridge University Press.

McDaniel, Eric L. 2016. "What Kind of Christian Are You? Religious Ideologies and Political Attitudes." Journal for the Scientific Study of Religion 55 (2): 288-307.

McKanan, Dan. 2011. Prophetic Encounters: Religion and the American Radical Tradition. Boston, MA: Beacon Press.

McKenna, George. 2007. The Puritan Origins of American Patriotism. New Haven, CT: Yale University Press.

McNamara, Patrick H. 1969. "Priests, Protest, and Poverty Intervention.” Social Science Quarterly 50(3): 695-702.

McQueeney, Krista. 2009. "We are God's Children, Y'all”: Race, gender, and Sexuality in Lesbian-and-Gay-Affirming Congregations.” Social Problems 56: 151-73. 
Mead, Sidney E. 1985. A Nation with the Soul of a Church. Atlanta, GA: Mercer University Press.

Mirola, William A. 2015. Redeeming Time: Protestantism and Chicago's Eight-Hour Movement, 1866-1912. Champaign, IL: University of Illinois Press.

Moody, Michael. 2002. “Caring for Creation: Environmental Advocacy by Mainline Protestant Organizations.” Pp. 237-64 in The Quiet Hand of God: Faith-Based Activism and the Public Role of Mainline Protestantism, edited by Robert Wuthnow and John Hyde Evans. Berkeley: University of California Press.

Moon, Dawne. 2004. God, Sex, and Politics: Homosexuality and Everyday Theologies. Chicago, IL: University of Chicago Press.

Morris, Aldon D. 1984. The Origins of the Civil Rights Movement: Black Communities Organizing for Change. New York: The Free Press.

Mundey, Peter, Hilary Davidson, and Patricia Snell Herzog. 2011. "Making Money Sacred: How Two Church Cultures Translate Mundane Money into Distinct Sacralized Frames of Giving.” Sociology of Religion 72(3): 303-26

Nepstad, Sharon E. 2008. Religion and War Resistance in the Plowshares Movement. Cambridge: Cambridge University Press.

Nepstad, Sharon Erickson. 2004. Convictions of the Soul: Religion, Culture, and Agency in the Central America Solidarity Movement. Oxford; New York: Oxford University Press. Nepstad, Sharon Erickson. 2017. "Religious Beliefs and Perceptions of Repression in the U.S. and Swedish Plowshares Movements." Pp. 246-68 in Religion and Progressive Activism: New Stories about Faith and Politics, edited by Ruth Braunstein, Todd Nicholas Fuist, and Rhys H. Williams. New York: NYU Press. 
Numrich, Paul D., and Fred Kniss. 2007. Sacred Assemblies and Civic Engagement: How Religion Matters for America's Newest Immigrants. New Brunswick, N.J: Rutgers University Press.

Oyakawa, Michelle. 2015. “Turning Private Pain into Public Action”: The Cultivation of Identity Narratives by a Faith-Based Community Organization." Qualitative Sociology 38(4):395-415.

Olson, Laura R. 2002. "Mainline Protestant Washington Offices and the Political Lives of Clergy." Pp. 54-79 in The Quiet Hand of God: Faith-Based Activism and the Public Role of Mainline Protestantism, edited by Robert Wuthnow and John Hyde Evans. Berkeley: University of California Press.

Olson, Laura R. 2011. "The Religious Left in Contemporary American Politics.” Politics, Religion and Ideology 12 (3): 271-294.

Olson, Laura R. 2017. “Collective Identity and Movement Solidarity among Religious Left Activists in the U.S.” Pp. 97-114 in Religion and Progressive Activism: New Stories about Faith and Politics, edited by Ruth Braunstein, Todd Nicholas Fuist, and Rhys H. Williams. New York: NYU Press.

Osterman, Paul. 2002. Gathering Power: The Future of Progressive Politics in America. Beacon Press.

Pattillo-McCoy, Mary. 1998. "Church Culture as a Strategy of Action in the Black Community." American Sociological Review 63(6): 767-84

Perry, Samuel L. and Andrew L. Whitehead. 2016. "Religion and Public Opinion Toward SameSex Relations, Marriage, and Adoption: Does the Type of Practice Matter?" Journal for the Scientific Study of Religion 55 (3): 637-651. 
Petz, M.L. and Corwin E. Smidt. 2015. "Generational Conversion? The Role of Religiosity in the Politics of Evangelicals." Journal for the Scientific Study of Religion 54 (2): 380-401.

Putnam, R. D., and D. E. Campbell. 2010. American Grace: How Religion Unites and Divides Us. New York: Simon \& Schuster, Inc.

Reed, Jean-Pierre, Rhys H. Williams, Kathryn B. Ward. 2016. “Civil Religious Contention in Cairo, Illinois: Priestly and Prophetic Ideologies in a 'Northern' Civil Rights Struggle.” Theory \& Society 45 (1): 25-55.

Rhodes, Jeremy. 2011. “Choosing Sides: An Exploration of Role Conflict among Evangelical Democrats." Sociology of Religion 72 (1): 28-49.

Sager, Rebecca. 2017. "Progressive Religious Activists and Democratic Party Politics.” Pp. 5675 in Religion and Progressive Activism: New Stories about Faith and Politics, edited by Ruth Braunstein, Todd Nicholas Fuist, and Rhys H. Williams. New York: NYU Press.

Schlozman, Kay Lehman, Sidney Verba, and Henry E. Brady. 2012. The Unheavenly Chorus: Unequal Political Voice and the Broken Promise of American Democracy. Princeton University Press.

Shortell, Timothy. 2001. "Radicalization of Religious Discourse in El Salvador: The Case of Oscar A. Romero." Sociology of Religion 62 (1): 87-103.

Siedentop, Larry. 2014. Inventing the Individual: The Origins of Western Liberalism. Cambridge, MA: Belknap/Harvard University Press.

Smidt, Corwin E. 2001. "Religion and American Public Opinion.” Pp. 96-117 in In God We Trust? Religion and American Public Life, edited by Corwin E. Smidt. Grand Rapids, MI: Baker. 
Smidt, Corwin, Kevin den Dulk, Bryan Froehle, James Penning, Stephen Monsma, and Douglas Koopman. 2010. The Disappearing God Gap?: Religion in the 2008 Presidential Election. Oxford University Press.

Smith, Christian. 1996. Disruptive Religion: The Force of Faith in Social-Movement Activism. New York: Routledge.

Smith, Christian. 1996. Resisting Reagan: The US Central America Peace Movement. Chicago, IL: University of Chicago Press.

Smith, Rogers M. 1997. Civic Ideals: Conflicting Visions of Citizenship in U.S. History. New Haven: Yale University Press.

Snarr, C. Melissa. 2011. All You That Labor: Religion and Ethics in the Living Wage Movement. NYU Press.

Stanczak, Gregory C. 2006. Engaged Spirituality: Social Change and American Religion. New Brunswick, N.J: Rutgers University Press.

Stout, Jeffrey. 2010. Blessed Are the Organized: Grassroots Democracy in America. Princeton, N.J.: Princeton University Press.

Sullivan, Amy. 2008. The Party Faithful: How and Why Democrats Are Closing the God Gap. New York: Scribner.

Swarts, Heidi J. 2008. Organizing Urban America: Secular and Faith-Based Progressive Movements. University of Minnesota Press.

Swartz, David R. 2014. Moral Minority: The Evangelical Left in an Age of Conservatism. University of Pennsylvania Press.

Tobey, Kristen. 2016. Plowshares: Protest, Performance, and Religious Identity in the Nuclear Age. University Park, PA: Penn State University Press. 
Verba, Sidney, Kay Lehman Schlozman, and Henry E. Brady. 1995. Voice and Equality: Civic Voluntarism in American Politics. Cambridge, MA: Harvard University Press.

Walls, N.E., Michael R. Woodford, and Denise L. Levy. 2014. "Religious Tradition, Religiosity, or Everyday Theologies? Unpacking Religion’s Relationship to Support for Legalizing Same Sex Marriage Among a College Student Sample." Review of Religious Research 56: $219-243$.

Warren, Mark R. 2001. Dry Bones Rattling: Community Building to Revitalize American Democracy. Princeton: Princeton University Press.

Whitman, Gordon. 2018. Stand Up!: How to Get Involved, Speak Out, and Win in a World on Fire. Oakland: Berrett-Koehler Publishers.

Wilcox, Melissa M. 2003. Coming out in Christianity: Religion, Identity, and Community. Bloomington: Indiana University Press.

Williams, Rhys H. 1995. “Constructing the Public Good: Social Movements and Cultural Resources." Social Problems 42 (1): 124-144.

Williams, Rhys H. 1999. "Visions of the Good Society and the Religious Roots of American Political Culture.” Sociology of Religion 60 (1): 1-34.

Williams, Rhys H. 2013. "Civil Religion and the Cultural Politics of National Identity in Obama’s America.” Journal for the Scientific Study of Religion 52 (2): 239-257.

Williams, Rhys H. 2017. "Conclusion: What Progressive Efforts Tell Us about Faith and Politics.” Pp. 348-64 in Religion and Progressive Activism: New Stories about Faith and Politics, edited by Ruth Braunstein, Todd Nicholas Fuist, and Rhys H. Williams. New York: NYU Press. 
Williams, Rhys H. and Susan M. Alexander. 1994. "Religious Rhetoric in American Populism: Civil Religion as Movement Ideology.” Journal for the Scientific Study of Religion 33 (1): $1-15$.

Williams, Rhys H., and N.J. J. Demerath III. 1991. "Religion and Political Process in an American City." American Sociological Review 56 (4): 417-31.

Wood, Benjamin. 2014. "Preserving Personhood: Quaker Individualism and Liberal Culture in Dialogue." Studies in Christian Ethics 27 (4): 474-89.

Wood, Richard L. 1999. "Religious Culture and Political Action." Sociological Theory 17 (3): 307-32.

Wood, Richard L. 2002. Faith in Action: Religion, Race, and Democratic Organizing in America. Chicago: University of Chicago Press.

Wood, Richard L., and Brad R. Fulton. 2015. A Shared Future: Faith-Based Organizing for Racial Equity and Ethical Democracy. University of Chicago Press.

Wood, Richard L., Brad Fulton, and Kathryn Partridge. 2012. "Building Bridges, Building Power: Developments in Institution-Based Community Organizing.”

Wuthnow, Robert. 1988. The Restructuring of American Religion: Society and Faith since World War II. Princeton, N.J.: Princeton University Press.

Wuthnow, Robert. 2006. Saving America?: Faith-Based Services and the Future of Civil Society. Princeton University Press.

Yamane, David. 2005. The Catholic Church in State Politics: Negotiating Prophetic Demands and Political Realities. Lanham, Md.: Rowman \& Littlefield Publishers.

Young, Michael P. 2002. “Confessional Protest: The Religious Birth of U.S. National Social Movements.” American Sociological Review 67 (5): 660-88. 
Young, Michael P. 2006. Bearing Witness to Sin. Chicago: University of Chicago Press.

Yukich, Grace. 2013. One Family Under God: Immigration Politics and Progressive Religion in America. New York: Oxford University Press.

Yukich, Grace. 2017. "Progressive Activism Among Buddhists, Hindus, and Muslims in the U.S.” Pp. 225-45 in Religion and Progressive Activism: New Stories about Faith and Politics, edited by Ruth Braunstein, Todd Nicholas Fuist, and Rhys H. Williams. New York: NYU Press. 